the very magnitude of his knowledge compels him to greater modesty. Perhaps that is the proper attitude he should adopt; if one admits that the final light that man seeks in this world should come from other sources which, though different from those of science, tend, however, to mould the human mind and its aspirations into a nobler and finer unity.

The freedom of the City of York was conferred on General Smuts when an invited party visited the city on Sept. 26.

At a reception given by the University of London on Sept. 28, the vice-chancellor delivered an address of welcome to the delegates to the centenary meeting, and then, by desire of the Senate, conferred the honorary degree of doctor of science, Honoris Causa, on the following :

General the Rt. Hon. Jan Christiaan Smuts, C.H., F.R.S. ;

Prof. Sir Frederick Gowland Hopkins, P.R.S.;

Sir Joseph John Thomson, O.M., F.R.S. ;

Sir Charles Scott Sherrington, O.M., G.B.E., F.R.S.;

The Rt. Hon. Lord Rutherford of Nelson, O.M., F.R.S.

\section{OFFICERS AND COUNCIL.}

Sir Alfred Ewing, lately principal and vicechancellor of the University of Edinburgh, has been elected by the General Committee president of the Association for next year, when the meeting will be held at York. Hitherto the president has assumed office at the inaugural meeting of the Association and has then given his presidential address. By an alteration of one of the Statutes, recommended by the Council and adopted by the General Com- mittee, the president will in future assume office on Jan. 1, will deliver his address at the annual meeting held during his year of office, and will retire at the end of the year. The advantages of these changes are stated by the Council as follows :

(1) The president will be responsible administratively for the major part of the preparation of arrangements for the annual meeting over which he is elected to preside, and his influence can be more directly brought to bear upon them.

(2) In particular, he will take the chair at the joint meeting of Organising Sectional Committees in the January preceding the annual meeting, which has now become a regular and principal part of the mechanism of preparing the programme.

(3) As a point of minor but still recognisable importance, he will arrive at the place of the annual meeting as president, not as president-elect, and possible confusion in the local public mind will be avoided.

(4) After the annual meeting he will still be in office to preside over those meetings of the Council at which matters arising out of the annual meeting are principally dealt with.

The new members of Council are Dr. J. Drever, Prof. T. E. Gregory, Prof. H. S. Hele-Shaw, Prof. E. B. Poulton, and Prof. A. M. Tyndall. Considerations of health would not permit Prof. F. J. M. Stratton to take full part in the preparations for the centenary meeting; and he cannot be present at next year's meeting. Prof. P. G. H. Boswell was therefore appointed as an additional general secretary. Prof. J. L. Myres, who has been one of the general secretaries of the Association since 1919, has intimated that he will not seek re-election after next year.

\title{
Obituary.
}

Prof. A. S. Pringle-Pattison.

$\mathrm{B}^{\mathrm{Y}}$ the death of Prof. Andrew Seth PringlePattison on Sept. 1, at the age of seventy. five years, philosophy lost one of the outstanding figures in a period of remarkable activity in that department. He was one of the first to see the significance for English thought of the impulse that came from the sympathetic study of Kant and Hegel in the 'sixties and 'seventies of last century. With the late Lord Haldane he organised the epoch-making manifesto contained in "Essays in Philosophical Criticism" which appeared in 1883 and included contributions from others who afterwards became famous in their several lines of research, J. S. Haldane, Bernard Bosanquet, W. R. Sorley, W. P. Ker, Sir Henry Jones, and James Bonar.

More cautious and more determined to make sure that no vital element in experience was being sacrificed to a first enthusiasm than some of his more ardent colleagues, Pringle-Pattison came forward in the next period of his philosophical development as a trenchant critic of what he held to be sinister features of the new movement. The doubts expressed in "Hegelian- ism and Personality" in 1887 seemed to be confirmed by the publication of Bradley's " Appearance and Reality " in 1893, and his essay in criticism of this work in "Man's Place in the Cosmos" seemed to separate him more widely still from his former idealistic associates. But the apparent recoil was only the preliminary to a more confident advance to the more personalistic form of that doctrine that found full expression in his Gifford Lectures in 1912-13 on "The Idea of God in the Light of Recent Philosophy" and has since had a growing influence both in England and America.

The general line of Pringle-Pattison's thought is indicated in the phrase which, so far as I know, he was the first to use of philosophy as " Criticism of Categories". The category prominent in nineteenth century thought was that of mechanical causation - the attempt to resolve everything into elements with which, as effect, it could be equated. This he held to be applicable (and possibly adequate) in certain limited spheres of phenomena, as in mechanics. But as we pass to other orders of fact, as to that of life, no preceding set of facts can account for their combination

No. 3231, VoL. 128] 
in a phenomenon essentially different from them. Here on the contrary "the true nature of the cause only becomes apparent in the effect". Equally certain was the insufficiency of any merely biological interpretation of the world of moral and religious experience. It is impossible to do justice to the sense of obligation and the instinctive admiration of unselfish devotion to far-reaching ends such as truth, beauty and moral perfection on any theory which takes the survival and material well-being of the species as the supreme goal and all else as instrumental to them-incidental results and by-products of the cosmic system. All explanation in a word of the higher by the lower is philosophically a hysteron proteron. Everything remains unintelligible until we invert the order of naturalistic explanation and go to work on the supposition that a purposeful moral intelligence is in reality the key to the world's meaning, the fact in the light of which all other phenomena must be read. In his own words, "every true philosophy is an attempted theodicy"-the vindication of a divine purpose in things.

However extravagant this claim may seem to those wedded to another order of thought, its vindication has been the dream of a long line of great thinkers since the time of Plato who found alone in the Good the adequate principle at once of the being of things and of our understanding of them. Pringle-Pattison's interpretation and defence of this thesis against prevalent forms of naturalism on one hand and forms of idealism, which sought for the principle of reality in a sphere beyond Good and Evil, on the other, ranks him with the great teachers, including Sir William Hamilton, who preceded him in the chair he so long occupied in Edinburgh.

An account of Pringle-Pattison's opinions gives, however, an imperfect idea of his work as a writer. It was the way in which he developed them out of a singular fullness of knowledge of contemporary philosophy, and the command of a peculiarly graceful style derived from an equally wide knowledge of the best in literature, that gave that work its peculiar distinction. Added to this he was known to his friends and his fellowtownsmen as a man of singular gentleness of manner and dignity of presence. He lived and looked the philosopher. Yet when called upon by the inheritance of an estate in the country to play the part of a Scottish laird, he surprised his friends by the firmness and efficiency of his management. Without the interest of his brother and colleague Prof. James Seth in the practical life of his city, and contrasting with 'Prof. Jim' in the more formal method of his teaching from written lectures, these self-limitations enabled him to give a certain completeness to the literary expression of his ideas in a long series of works of uniform distinction, closed only last year by the publication of his "Studies in the Philosophy of Religion", described by the Times of Sept. 2 as " among the best in the apologetics of rational theism ".

Pringle-Pattison was LL.D. in his own university, honorary D.C.L. of Oxford, and a fellow of the British Academy. Among his early friends, besides those already mentioned, were Ambassador J. G. Schurman and the late Lord Balfour, who founded the lectureship under that name in the University of Edinburgh with the express purpose that Andrew Seth, as we then knew him, should be the first to hold it. Seldom have youthful appointments been better justified. J. H. Muirhead.

WE regret to announce the following deaths:

Sir Gregory Foster, Bart., formerly provost of University College and vice-chancellor of the University of London, author of many educational works, on Sept. 24, aged sixty-five years.

Dr. Charles A. Keane, formerly principal of the Sir John Cass Technical Institute, Aldgate, on Sept. 18, aged sixty-seven years.

\section{News and Views.}

As we go to press, we have received the following radiogram, dated Sept. 28, from Sir C. V. Raman, F.R.S., and S. Bhagavantam: "Experimental demonstration of spin of light.-The depolarisation of Rayleigh scattering of monochromatic light in carbon dioxide gas does not diminish to one quarter of its value when spectroscopically separated from rotational scattering, as demanded by existing theories of radiation. The actual observed diminution, from 10 per cent to 6 per cent, is quantitatively explicable, assuming that common light consists of spinning quanta possessing one Planck unit of angular momentum.-C. V. Raman and S. Bhagavantam."

ThIs is the centenary of the discovery of miners' safety fuse-more generally known as Bickford fuseby William Bickford. He was a Devonshire man, but having married a Cornishwoman, he went to live in the little village of Tuckingmill in the mining area of Cornwall, and there he first started his experiments on safety fuse. In this he was actuated by humanitarian motives, for he had nothing whatever to do with mining, his business being that of a currier. Blasting operations as conducted one hundred years ago were exceedingly difficult and dangerous. The only explosive then known was gunpowder, and though the handling did not involve any great risk, the methods in use for conveying the fire to the charge were definitely dangerous. It was at this stage that accidents were of such frequent occurrence, and the old records in Cornwall and elsewhere show that the fatalities were very great. But it was the number of permanently maimed men utterly incapacitated for work through the loss of fingers, an arm, or a leg, visible evidence of the hazardous nature of mining, which spurred Bickford on with his work. The most effective and 